\title{
Analisis Unjuk Kerja Improved Sinc Power Pulse pada Sistem OFDM Melalui Kanal Frequency Selective Fading
}

\author{
Kadek Agus Mahabojana Dwi Prayoga ${ }^{1}$, Ni Made Esta Dewi Wirastuti ${ }^{2}$, Nyoman Pramaita ${ }^{3}$ \\ Submission: 13-07-2019, Accepted: 02-09-2019
}

\begin{abstract}
The combination OFDM (orthogonal frequency division multiplexing), and pulse shaping are expected to reduce the effects of Inter Carrier Interference (ICI) and error occurred. This study aimed to compare the performance of OFDM without pulse shaping and OFDM with pulse shaping Improved Sinc Power (ISP) pulse through Frequency Selective Fading channel, in terms of BER (bit error rate) vs. Eb/No (energy per bit to noise power spectral density ratio). This study implemented simulation using Matlab R2018a. The results of the simulation OFDM with ISP pulse system performance has better results than OFDM without pulse shaping. In the transmission Frequency Selective Fading channel, to reach $10^{-1}$ BER value in OFDM with ISP pulse was required $\mathrm{Eb} / \mathrm{No}$ of $2 \mathrm{~dB}$. While the OFDM without pulse shaping systems required Eb/No $10 \mathrm{~dB}$.
\end{abstract}

Intisari- Kombinasi antara sistem OFDM (orthogonal frequency division multiplexing) dan Pulse Shaping mampu mengurangi Inter Carrier Interference (ICI) dan error yang terjadi. Penelitian ini bertujuan untuk mengetahui perbandingan performansi dari sistem OFDM tanpa pulse shaping dan OFDM dengan pulse shaping Improved Sinc Power (ISP) pulse yang melalui kanal Frequency Selective Fading, ditinjau dari BER (bit error rate) berbanding Eb/No (energy per bit to noise power spectral density ratio). Penelitian ini menggunakan metode simulasi dengan menggunakan program Matlab R2018a. Hasil dari simulasi didapat unjuk kerja sistem OFDM dengan pulse shaping ISP pulse memiliki hasil yang lebih baik dari OFDM tanpa pulse shaping. Pada kanal transmisi Frequency Selective Fading untuk mencapi nilai BER sebesar $10^{-1}$ sistem OFDM dengan pulse shaping ISP pulse dibutuhkan Eb/No sebesar $2 \mathrm{~dB}$. Sedangkan pada sistem OFDM tanpa pulse shaping dibutuhkan Eb/No sebesar $10 \mathrm{~dB}$.

Kata Kunci- OFDM, Pulse Shaping, ICI, ISP pulse, Frequency Selective Fading.

\section{PENDAHULUAN}

Teknologi LTE (Long Term Evolution) merupakan salah satu teknologi yang digunakan dalam mewujudkan layanan komunikasi yang cepat dan baik pada komunikasi wireless. Teknologi LTE ini menggunakan OFDM (Orthogonal Frequency Division Multiplexing) untuk downlink dan SCFDMA (Single-Carrier Frequency Division Multiple Access) untuk uplink. OFDM merupakan teknik modulasi multicarrier, dimana antar subcarrier satu dengan yang lain saling

\footnotetext{
${ }^{1}$ Mahasiswa, Program Studi Magister Teknik Elektro Fakultas Teknik Universitas Udayana, Jalan Panglima Besar Sudirman Denpasar, Bali 80232 (telp: 0361-555225; fax: 0361-4321982; email:mahabojanadwil@gmail.com)

2, 3 Dosen,Jurusan Teknik Elektro dan Komputer Fakultas Teknik Universitas Udayana, Jln. Jalan Kampus Bukit Jimbaran 80361 INDONESIA (telp: 0361-703315; fax: 0361-4321; e-mail: dewi.wirastuti@ee.unud.ac.id)
}

orthogonal. Karena sifat orthogonal ini, maka antar subcarrier dibuat overlapping tanpa menimbulkan efek ISI (inter symbol interference). Dengan multiplexing subcarrier yang dilakukan secara overlap tersebut tentu saja dapat menghemat bandwidth. Proses yang dilakukan sama dengan teknik modulasi multicarrier, yang membedakan hanya pada penggunaan subcarrier yang saling orthogonal pada masingmasing subkanal [1].

Namun, dalam teknik OFDM itu sendiri terdapat beberapa kelemahan, salah satunya sangat sensitif terhadap frequency offset yang akan menyebabkan ICI. Adanya ICI akan mengurangi performansi dari sistem OFDM [2]. Sehingga reduksi ICI secara akurat dan efisiensi sangat dibutuhkan untuk demodulasi data yang diterima. Beberapa metode telah diusulkan dalam mereduksi ICI ini diantaranya dengan metode pulse shaping.

Salah satu metode dalam mengatasi penyebab utama ICI adalah dengan pulse shaping dimana pada sistem OFDM subcarrier di filter ketika masih dalam keadaan saling orthogonal sehingga pada saat di penerima efek interferensi dari sidelobe subcarrier lain telah tereduksi [3]. Kombinasi OFDM dengan Pulse Shaping menggunakan Improved Sinc Power (ISP) pulse diharapkan dapat menghasilkan sistem yang lebih baik dengan menggabungkan keunggulan masingmasing sistem.

Jadi pada penelitian ini, akan melakukan simulasi unjuk kerja dari sistem OFDM tanpa menggunakan teknik Pulse Shaping dan sistrm OFDM dengan menggunakan teknik Pulse Shaping yaitu jenis ISP pulse pada kanal Frequency Selective Fading. Kemudian membandingkan unjuk kerja dari masingmasing sistem untuk mengetahui sistem mana yang memiliki unjuk kerja yang paling baik. Kebaruan dari peneliatan ini dari penelitian sebelumnya yaitu menggunakan kanal transmisi Frequency Selective Fading dan penelitian ini dilakukan simulasi yang diarahkan kepada standar 4G-LTE sehingga parameter-parameter yang digunakan mengacu pada standar 4G-LTE tersebut.

\section{OFDM Improved SinC PoWer PULSE DAN FREQUENCY SELECTIVE FADING}

\section{A. OFDM (Orthogonal Frequency Division Multiplexing)}

Orthogonal Frequency Division Multiplexing (OFDM) merupakan teknik multiplexing yang digunakan pada sistem komunikasi digital dengan menggunakan beberapa frekuensi yang akan membagi bandwidth menjadi beberapa subcarrier yang saling orthogonal. OFDM akan membagi data serial dengan bit rate tinggi menjadi $\mathrm{N}$ buah data parallel dengan bit rate rendah yang kemudian ditransmisikan melalui beberapa subcarrier tersebut [4]. 


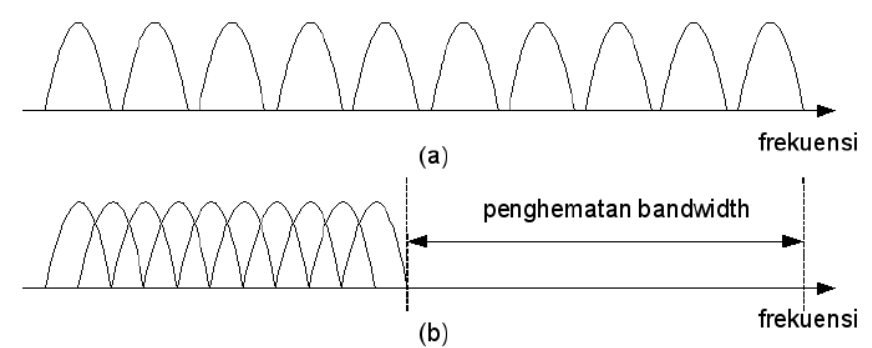

Gambar 1 : Perbandingan FDM dan OFDM

\section{B. ISP (Improved Sinc Power)Pulse}

Pada spektrum OFDM, setiap subcarrier-nya terdiri dari main lobe dan banyak sidelobe. Ketika othogonalitas diantara subcarrier berkurang maka side lobe tersebut akan berpotensi memunculkan daya ICI pada daerah tengah dari setiap subcarrier. Daya ICI akan meningkat ketika frekuensi offset meningkat. Tujuan penggunaan pulse shaping ini adalah untuk menghilangkan side lobe tersebut sehingga ICI akan tereduksi dan kemudian mampu meningkatkan performansi dari sistem OFDM tersebut [5].

Improved Sinc power Pulse (ISP) sebagai modifikasi bentuk pulse yang dijabarkan dalam persamaan $P_{3 s p}(f)=e^{-a(f)^{2}} \operatorname{sinc}^{n}(f$, kemudian frequency offset disubstusi kedalam persamaan menjadi:

$$
P_{I S P}(\Delta f)=e^{-a(\Delta f T)^{2}} \sin ^{n}(\Delta f
$$

Dimana ، menyatakan carrier frequency offset diantara osilator pengirim dan penerima dan $\Delta$ menyatakan nilai normalized frequency offset. Parameter a digunakan untuk mengatur amplitudo dan $\mathrm{n}$ menyatakan derajat fungsi sinc.

\section{AWGN (Additive White Gaussian Noise)}

AWGN merupakan Salah satu jenis noise yang ada pada sistem komunikasi adalah noise thermal. Noise ini merusak sinyal dalam bentuk aditif, yaitu ditambahkan ke sinyal utama. Maka, noisethermal pada perangkat penerima ini disebut Additive White Gaussian Noise (AWGN). Arti dari kata additive ialah bahwa noise ini bersifat menambah power spectral density dari sinyal transmisi, white artinya memiliki persebaran merata pada semua band, dan merupakan noise yang terbangkitkan dengan distribusi Gaussian yaitu dengan nilai mean nol dan standar deviasi bernilai satu [6].

\section{Frequency Selective Fading}

Suatu sinyal dikatakan melalui frequency selective fading, jika sinyal yang ditransmisikan itu memiliki lebar pita (bandwidth) lebih besar dari bandwidth kanal radio dan tanggapan impuls kanal yang memiliki delay spread lebih besar dari periode symbol. Sinyal yang diterima terdiri dari beberapa sinyal yang ditransmisikan, yang sudah teredam dan terjadi waktu tunda sehingga sinyal yang diterima akan terdistorsi. Frequency Selective Fading menyebabkan terjadi disperse waktu dari simbol yang ditransmisikan. Kanal seperti ini yang menyebabkan interferensi antar simbol (ISI), [7].
Gambar 2 menunjukan karakteristik dari kanal frequency selective fading.
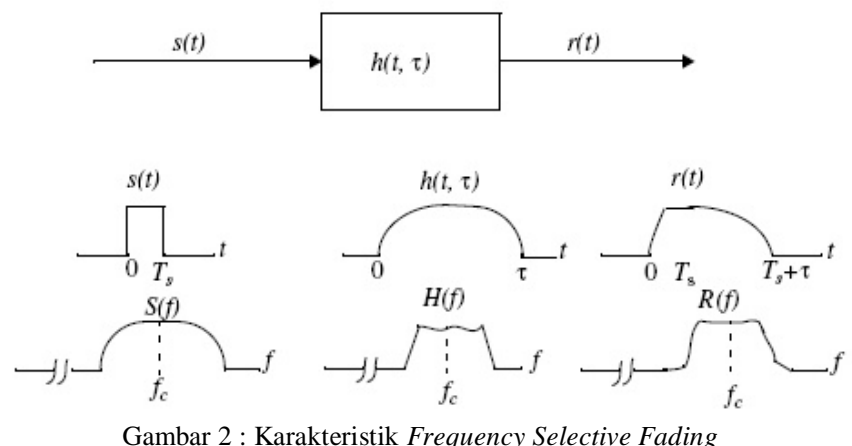

\section{E. Distribusi Rayleigh}

Pada kanal komunikasi bergerak, distribusi Rayleigh biasa digunakan untuk menjelaskan perubahan waktu dari selubung sinyal flatfading yang diterima atau selubung dari satu komponen multipath yang telah diasumsikan sebelumnya menjadi distribusi Rayleigh. Distribusi Rayleigh digunakan untuk mendeskripsikan keadaan pada suatu kanal dimana distribusi Rayleigh mempunyai probabilitas density function sesuai dengan Persamaan (2) sebagai berikut [7]:

$p(r)=\left\{\begin{array}{cc}\frac{r}{\sigma^{2}} \exp \left(\frac{r^{2}}{2 \sigma^{2}}\right) & (0 \leq r \leq \infty) \\ 0 & (r<0)\end{array}\right.$

\section{F. ICI (Inter Carrier Interference)}

ICI terjadi karena adanya pergeseran frekuensi kerja sistem OFDM atau sering disebut sebagai frekuensi offset. Penyebab frekuensi offset adalah Doppler shift yang diakibatkan adanya pergerakan relatif antara pemancar dan penerima dan juga disebabkan adanya perbedaan antara frekuensi osilator di penerima dan di pemancar [8].

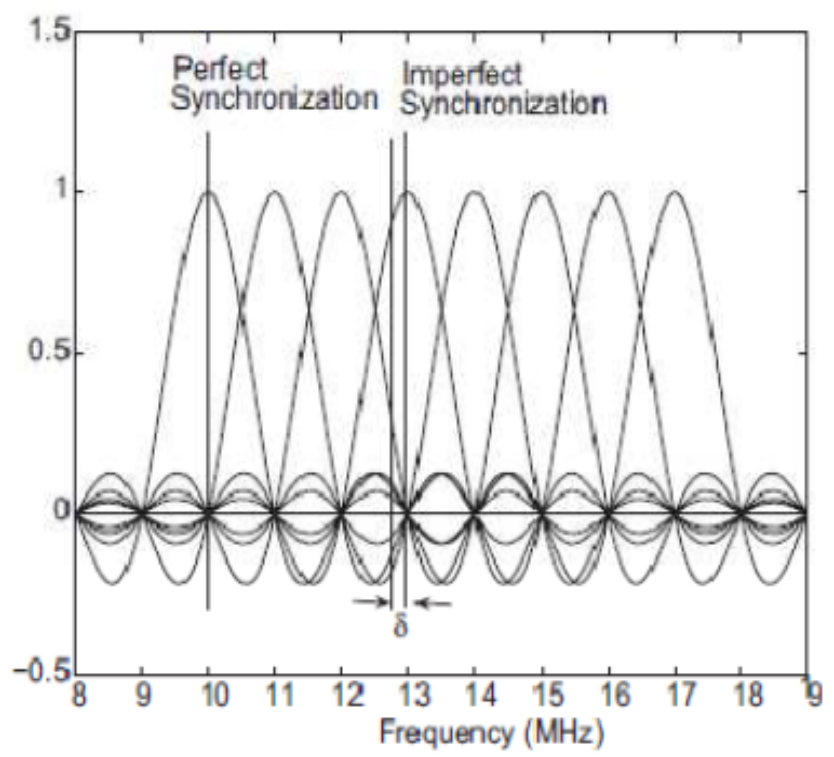

Gambar 3 : Inter Carrier Interference 


\section{METODE PENELITIAN}

Penelitian ini menggunakan metode simulasi dimana bertuuan untuk mengetahui unjuk kerja dari Improved Sinc Power (ISP) pulse pada sistem OFDM melalui kanal Frequency Selective Fading. Simulasi yang akan dilakukan pertama yaitu dengan menjalankan sistem OFDM tanpa menggunakan pulse shaping, kemudian menjalankan simulasi sistem OFDM yang menggunakan pulse shaping ISP pulse. Selanjutnya membandingkan unjuk kerja dari kedua sistem tersebut.

\section{A. Alur Penelitian}

Tahapan penelitian yang dilakukan dimulai dengan melakukan pomodelan sistem dalam software Matlab R2018a. Hasil dari simulasi yang dilakukan pada software Matlab R2018a berupa grafik dan nilai BER berbanding Eb/No yang kemudian akan analisis.

\section{B. Parameter Simulasi}

Adapun parameter simulasi yang digunakan dalam pemodelan sistem OFDM tanpa pulse shaping dan sistem OFDM dengan ISP pulse dapat dilihat pada Tabel 1.

TABEL I

PARAMETER SIMULASI

\begin{tabular}{|c|c|}
\hline Parameter & Nilai yang digunakan \\
\hline Jumlah subcarrier & 64 \\
\hline Jumlah simbol FFT & 64 \\
\hline Tipe modulasi & QPSK \\
\hline Zero Padding & 14 \\
\hline Jumlah bit per OFDM & 50 \\
\hline Guard interval type & Cyclic prefix \\
\hline Panjang cyclic prefix & 16 \\
\hline Nilai Eb/No & $-10: 1: 10$ \\
\hline Jumlah bit yang input & 100.000 bit (Random) \\
\hline Pulse Shaping type & ISP pulse \\
\hline Jenis Kanal & AWGN + Frequency selective \\
& fading \\
\hline
\end{tabular}

\section{Pemodelan Sistem OFDM ISP Pulse}

Pada penelitian ini, pemodelan sistem OFDM dikombinasikan dengan ISP pulse pada kanal Frequency Selective Fading dapat dilihat pada Gambar 4.

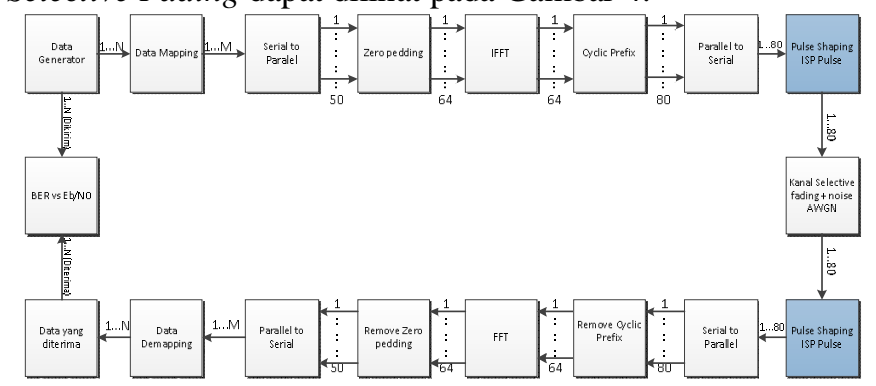

Gambar 4 : Pemodelan Sistem OFDM dengan ISP pulse
Adapun penjelasan masing-masing blok diagram sistem OFDM dengan penerapan metode pulse shaping adalah sebagai berikut:

\section{- Blok Pengirim}

Data yang dikirimkan berupa input bilangan biner secara acak dimana pengiriman data akan melalui blok-blok diagram sebagai berikut:

\section{Input Data}

Input data adalah deretan data yang dibangkitkan pada single user menggunakan fungsi randint pada Matlab, sehingga deretan data memiliki pola acak (random) berupa data biner bernilai 0 dan 1 . Pada simulasi dilakukan pengiriman sebanyak 100.000 bit diinisialisasikan jumlahnya dari 1 sampai dengan $\mathrm{N}$ dimana $\mathrm{N}$ bernilai 100.000.

\section{MappingData}

Pada blok ini data-data biner akan diubah menjadi simbolsimbol data sesuai dengan konstelasi modulasi digital yang digunakan. Signal mapper yang dipakai dalam penelitian ini adalah QPSK dimana konstelasi dari mapper QPSK menghasilkan 2 bit per simbol untuk dimodulasikan. Sehingga yang awalnya ada jumlah bit dari 1 sampai $\mathrm{N}$ akan menghasilkan jumlah simbol sebanyak N/2 simbol yang kemudian dinotasikan dengan 1 sampai dengan $M(M=N / 2)$.

\section{Serial to parallel}

Blok serial to parallel berfungsi untuk mengubah deretan data serial menjadi deretandata parallel dimana tujuannya adalah untuk menaikkan time periode dari deretan data dengan sinyal yang masuk sehingga akan terjadi penurunan rate. Dalam proses serial to parallel ini akan menghasilkan matriks dengan 50 baris dan beberapa kolom yang mana jumlah kolom disesuaikan berdasarkan hasil pembagian variabel $\mathrm{X}$ dengan 50 (subcarrier). Tiap satu kolom yang terdiri atas 50 baris dalam matriks hasil perubahan serial to parallel merupakan satu simbol OFDM.

\section{Add Zero Padding}

PadaZero Padding (ZP), dilakukan penyisipan bit nol pada tiap-tiap simbol untuk mencegah terjadinya Inter Carrier Interference (ICI) dan bertujuan untuk agar deretan data parallel sesuai dengan jumlah simbol IFFT. Jumlah zero padding yang digunakan adalah 14, sehingga setiap simbol OFDM memiliki ukuran 64 baris.

\section{IFFT (Invers Fast Fourier Transform)}

Blok IFFT memiliki fungsi sebagai baseband modulator yang akan membangkitkan nilai subcarrier yang saling orthogonal dimana dalam simulasi hasil simbol mapper akan diproses dengan menggunakan pemanggilan fungsi ifft pada Matlab. Dalam penelitian ini digunakan jumlah point IFFT atau jumlah subcarrier yang digunakan adalah sebanyak 64 . 


\section{Add Cyclix Prefix}

Penambahan Cyclic Prefix (CP) bertujuan untuk mencegah terjadinya Inter Simbol Interference (ISI) yang dapat dilakukan dengan penambahan simbol secara periodik atau yang dikenal dengan penambahan pilot. Penambahan pilot ini dapat mengurangi terjadinya Inter Carrier Interference (ICI) dan membantu menjaga ke-orthogonalitasan sinyal. Besarnya jumlah simbol yang ditambahkan adalah 1/4 dari jumlah subcarrier yang digunakan dimana sinyal pilot ini nantinya akan dihilangkan pada sisi penerima sehingga yang diterima hanya sinyal atau deretan data informasi saja. Berdasarkan penelitian ini panjang CP yang digunakan sebesar 16 baris sehingga panjang simbol OFDM akan berubah dari 1 sampai ke 80 .

\section{Parallel to serial}

Blok ini berfungsi untuk menggabungkan data parallel berupa output IFFT menjadi data serial yang disebut sebagai satu simbol OFDM dimana apabila output IFFT memiliki ukuran matriks 80x1 maka matriks output data parallel to serial akan menjadi 1x80.

\section{Pulse Shaping Function}

Blok ini berfungsi membentuk pulse dari simbol-simbol yang ada. Setiap simbol yang ditransmisikan akan dikalikan dengan fungsi pulse yang digunakan dimana pada simulasi ini digunakan jenis pulse shaping Rectangular Pulse dan dibandingkan dengan pulse shaping Improved Sinc power Pulse(ISP). Tujuan penggunaan metode pulse shaping adalah untuk menghilangkan daya side lobe yang dapat berpotensi memunculkan daya ICI dimana penggunaan Pulse Shaping dapat mengurangi daya ICI.

\section{- Pemodelan Kanal}

Pada simulasi sistem OFDM ini digunakan jenis kanal Frequency selective fading yang terdistribusi Rayleigh dimana masing-masing respon kanal yang terdistribusi Rayleighakan ditambahkan dengan noise AWGN.

\section{- Pemodelan ICI}

Untuk pemodelan sistem yang mengalami efek Inter Carrier Interference (ICI) dinyatakan dengan persamaan (2.19) sebagai berikut:

$$
s_{m}=\left(s_{m} P(-\Delta f)+\sum_{\substack{k=0 \\ k \neq m}}^{N-1} s_{h i} P\left(\frac{m-k}{T}-\Delta f\right)\right) e^{j \theta}+n_{m}
$$

Adanya efek ICI pada simbol yang diterima dinyatakan dengan variable $\Delta \mathrm{f}$ yang disebut dengan carrier frequency offset dimana selanjutnya besarnya nilai carrier frequency offset tersebut akan dinormalisasi terhadap besarnya nilai subcarrier spacing yang kemudian disebut normalized frequency offset sebesar $\Delta \mathrm{fT}$. Nilai $\Delta \mathrm{fT}$ atau $\varepsilon$ inilah yang akan menunjukkan seberapa besar pergeseran subcarrier yang dideteksi oleh oscilator penerima dimana nilai dari $|\Delta \mathrm{fT}| \leq 1$. Dalam simulasi pemodelan rumus tersebut dilakukan setelah output dari parallel to serial.
- Blok Penerima

Setelah melewati proses pada kanal maka data akan diproses di bagian penerima dimana prosesnya merupakan kebalikan fungsi dari blok pengirim. Adapun penjelasan blokblok diagram di bagian penerima atau receiver adalah sebagai berikut:

\section{Pulse Shaping Function}

Pada sisi receiver juga terdapat proses pulse shaping dimana proses pulse shaping yang terjadi di receiver merupakan kebalikan dari proses pulse shaping pada sisi transmitter.

\section{Serial to Parallel}

Setelah melewati kanal, data informasi yang berbentuk serial akan diterima dan kemudian dibagi ke dalam setiap lengan menjadi data parallel.

\section{Remove Cyclix Prefix}

Simbol Cyclic Prefix yang telah disisipkan pada data sebelumnya di bagian transmitter akan dipisahkan dan dibuang kembali sehingga hanya diperoleh data masukan yang sebenarnya dikirim. Proses ini merupakan kebalikan dari proses penambahan cyclic prefix pada blok pengirim. Sehingga jumlah baris OFDM yang sebelumnya 80 baris dalam satu simbol sekarang menjadi 64 baris dalam satu simbol OFDM.

\section{Fast Fourier Transform (FFT)}

FFT merupakan kebalikan dari proses IFFT dimana FFT digunakan untuk menganalisis sinyal pada domain frekuensi. Ukuran FFT ini sama dengan ukuran IFFT yaitu 64 dan menggunakan data dalam aliran parallel.

\section{Remove Zero Padding}

Simbol Zero Padding yang disisipkan sebelumnya pada bagian transmitter akan dipisahkan kembali pada blok ini sehingga didapatkan data masukan awal. Sehingga dalam satu simbol OFDM akan kembali dihasilkan 50 baris.

\section{Parallel to Serial}

Blok ini berfungsi untuk menggabungkan kembali data informasi setiap lengan sebelumnya yang berbentuk parallel menjadi deretan data serial. Kemudian pilot yang ditambahkan pada sisi transmisi akan dihilangkan kembali setelah data berbentuk serial sehingga output yang diterima berupa data informasi saja.

\section{DemappingData}

Demapping berfungsi untuk merekontruksi kembali data yang dikirim berdasarkan nilai simbol data yang diterima agar sesuai dengan konstelasi modulasi yang digunakan pada sisi transmitter.

\section{- Perhitungan BER}

Salah satu cara untuk mengetahui performansi dari suatu sistem komunikasi dapat dilihat dengan menghitung jumlah 
Majalah Ilmiah Teknologi Elektro, Vol. 18, No. 3, September-Desember 2019

DOI: https://doi.org/10.24843/MITE.2019.v18i03.P04

data yang error pada receiver yang dikenal dengan Bit Error Rate (BER). BER dilakukan dengan membandingkan data yang diterima dengan data yang dikirim yang kemudian dibandingkan dengan Eb/No (Energy Bit per Noise).

\section{HASIL DAN PEMBAHASAN}

\section{A. Hasil Simulasi Sistem OFDM Tanpa Pulse Shaping}

Simulasi OFDM tanpa pulse shaping bertujuan untuk mengetahui unjuk kerja dari sistem OFDM pada kanal transmisi Frequency Selective Fading berdasarkan parameter BER vs Eb/No. Grafik unjuk kerja sistem OFDM tanpa pulse shaping pada kanal AWGN dan Frequency Selective Fadingditunjukan pada Gambar 5.

Berdasarkan pada Gambar 5, pada sistem OFDM tanpa pulse shaping untuk mencapi nilai BER sebesar $10^{-2}$ pada kanal transmisi AWGN dibutuhkan Eb/No sebesar $12 \mathrm{~dB}$. Sedangkan pada kanal transmisi Frequency Selective Fading dibutuhkan Eb/No sebesar 20 dB.

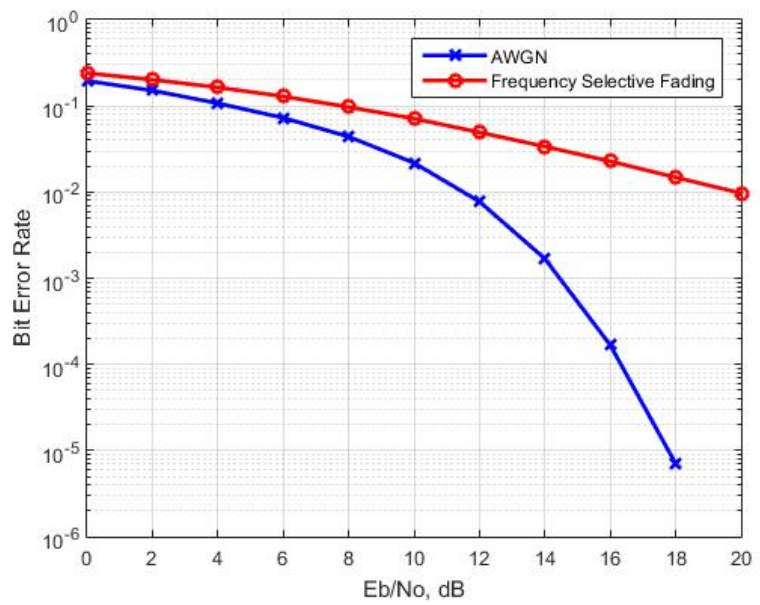

Gambar 5 : BER OFDM Tanpa pulse shaping pada Kanal AWGN dan Frequency Selective Fading

Dari Gambar 5 dapat dilihat bahwa pada kanal transmisi AWGN memiliki nilai BER lebih kecil dari kanal transmisi Frequency Selective Fading. Hal itu karena pemodelan AWGN tidak melewatkan data yang dikirimkan pada sebuah kanal atau saluran komunikasi yang memiliki efek fading, melainkan hanya menambahkan pengaruh noise AWGN dalam proses transmisi antara pengirim dan penerima.

\section{B. Hasil Simulasi Sistem OFDM ISP Pulse}

Simulasi sistem OFDM dengan pulse shaping Improved Sinc Power (ISP) pulse dilakukan mengikuti pemodelan sistem OFDM ISP pulse pada Gambar 4. Simulasi ini bertujuan untuk mengetahui unjuk kerja dari sistem OFDM dengan menggunakan pulse shaping ISP pulse pada kanal transmisi Frequency Selective Fading berdasarkan parameter BER vs Eb/No. Grafik unjuk kerja sistem OFDM dengan pulse shaping ISP pulse pada kanal transmisi AWGN dan Frequency Selective Fading ditunjukan pada Gambar 6.

Kadek Agus Mahabojana Dwi Prayoga: Analisis Unjuk Kerja Improved...

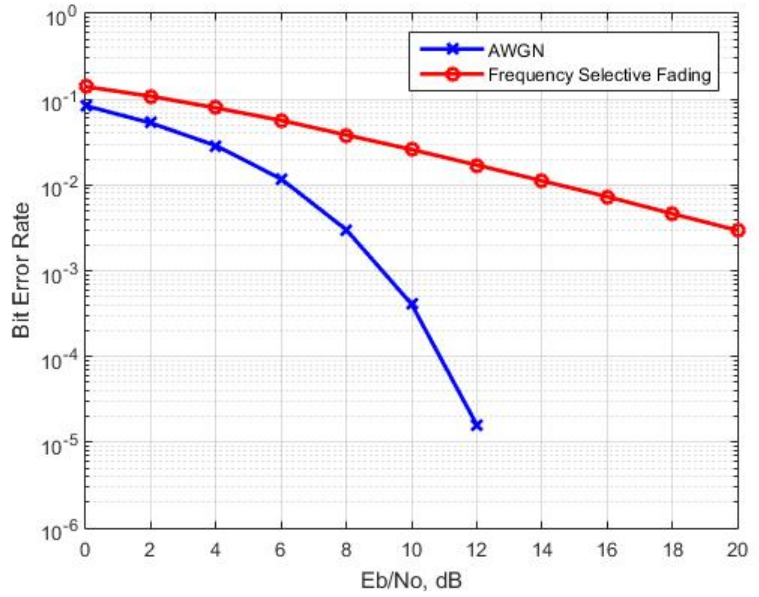

Gambar 6 : BER OFDM ISP pulse pada Kanal AWGN dan Frequency Selective Fading

Berdasarkan pada Gambar 6, pada sistem OFDM ISP pulse untuk mencapi nilai BER sebesar $10^{-2}$ pada kanal transmisi AWGN dibutuhkan Eb/No sebesar 6 dB. Sedangkan pada kanal transmisi Frequency Selective Fadingdibutuhkan Eb/No sebesar $14 \mathrm{~dB}$.

Dapat dilihat pada Gambar 6 kanal transmisi Frequency Selective Fading memiliki nilai BER lebih besar dari kanal transmisi AWGN. Hal ini dikarenakan pada kanal transmisi Frequency Selective Fading data yang dikirimkan tidak hanya melewati kanal atau saluran komunikasi yang memiliki efek fading saja, melainkan ada penambahan noise AWGN dalam proses transmisi antara pengirim dan penerima.

\section{Perbandingan Unjuk Kerja Sistem OFDM Tanpa Pulse Shaping dengan Sistem OFDM ISP Pulse}

Perbandingan antara hasil simulasi sistem OFDM tanpa pulse shaping dan OFDM dengan ISP pulse berdasarkan parameter BER vs Eb/No. Grafik dari perbandingan sistem OFDM tanpa pulse shaping dan OFDM ISP pulse ditunjukan pada Gambar 7.

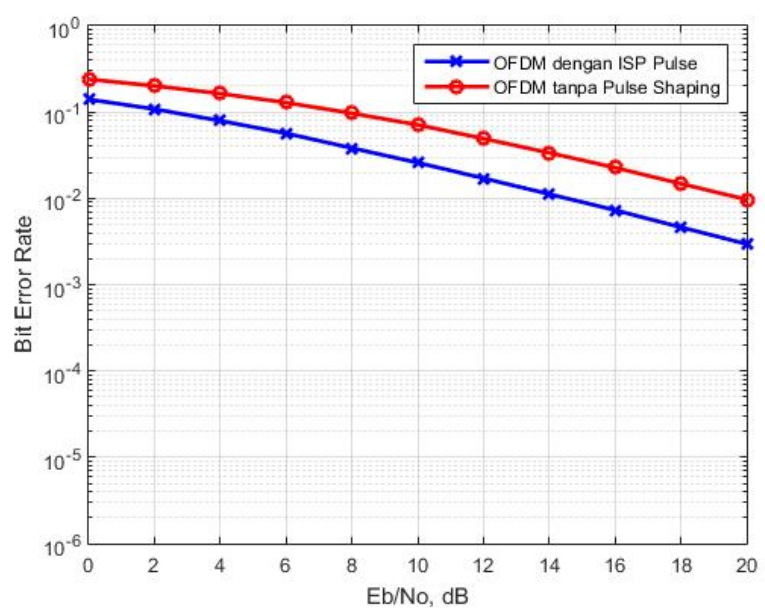

Gambar 7 :Perbandingan BER OFDM ISP pulse dan OFDM tanpa pulse shaping pada Kanal Frequency Selective Fading 
Berdasarkan pada Gambar 7, pada kanal transmisi Frequency Selective Fading untuk mencapi nilai BER sebesar $10^{-1}$ pada sistem OFDM ISP pulse dibutuhkan Eb/No sebesar $2 \mathrm{~dB}$. Sedangkan pada sistem OFDM tanpa pulse shaping dibutuhkan $\mathrm{Eb} / \mathrm{No}$ sebesar $10 \mathrm{~dB}$.

Hasil perbandingan simulasi didapatkan bahwa unjuk kerja sistem OFDM dengan ISP pulse memiliki unjuk kerja yang lebih baik dari pada sistem OFDM tanpa pulse shapingpada kanal transmisi Frequency Selective Fading. Hal ini disebabkan karena sistem OFDM tanpa pulse shaping pada penelitian ini merupakan sistem OFDM dengan penerapan frequency offset dimana frequency offset ini mengakibatkan pergeseran side lobe dari beberapa subcarrier yang akan menimbulkan ICI (Intercarrier Interference) terhadap subcarrier tersebut. ICI akan menyebabkan hilangnya orthogonalitas dari suatu subcarrier dimana subcarrier yang telah kehilangan ortoghonalitas-nya menyebabkan side lobe dari subcarrier tersebut tidak lagi bernilai nol pada frekuensi tengah dari subcarrier tersebut. Hal ini menyebabkan performansi dari sistem OFDM menjadi semakin buruk dimana ditunjukkan dengan nilai BER yang dihasilkan semakin tinggi. Oleh karena itu diterapkanlah pulse shaping ISP pulse untuk membantu mereduksi ICI pada sistem OFDM dimana ISP pulse mampu menghilangkan pengaruh dari pergeseran side lobe yang berpotensi menimbulkan ICI sehingga daya pada setiap subcarrier tidak akan terinterferensi oleh side lobe dari subcarrier lainnya.

\section{KESIMPULAN}

Berdasarkan hasil simulasi dan pembahasan yang telah dilakukan maka diperoleh beberapa kesimpulan diantaranya sebagai berikut:

1. Pada unjuk kerja sistem OFDM tanpa pulse shaping, kanal transmisi AWGN memiliki nilai BER yang lebih rendah dari kanal transmisi Frequency Selective Fading. Untuk mencapi nilai BER sebesar $10^{-2}$ pada kanal transmisi AWGN dibutuhkan Eb/No sebesar $12 \mathrm{~dB}$. Sedangkan pada kanal transmisi Frequency Selective Fading dibutuhkan Eb/No sebesar $20 \mathrm{~dB}$.

2. Pada unjuk kerja sistem OFDM dengan pulse shaping Improved Sinc Power (ISP) pulse, kanal transmisi AWGN memiliki nilai BER yang lebih rendah dari kanal transmisi Frequency Selective Fading. Untuk mencapi nilai BER sebesar $10^{-2}$ pada kanal transmisi AWGN dibutuhkan Eb/No sebesar $6 \mathrm{~dB}$. Sedangkan pada kanal transmisi Frequency Selective Fading dibutuhkan Eb/No sebesar $14 \mathrm{~dB}$.

3. Pada perbandingan unjuk kerja dari sistem OFDM tanpa pulse shaping dan OFDM dengan pulse shaping ISP pulse didapat unjuk kerja dari sistem OFDM dengan pulse shaping ISP pulse lebih baik. Pada kanal transmisi Frequency Selective Fading untuk mencapi nilai BER sebesar $10^{-1}$ pada sistem OFDM dengan pulse shaping
ISP pulse dibutuhkan Eb/No sebesar 2 dB. Sedangkan pada sistem OFDM tanpa pulse shaping dibutuhkan Eb/No sebesar $10 \mathrm{~dB}$.

\section{REFERENSI}

[1] T. B. Purwanto, "Analisis Unjuk Kerja Teknik MIMO STBC dan VBlast Pada Sistem Orthogonal Frequency Division Multiplexing”. Skripsi. Jurusan Teknik Elektro Fakultas Teknik Universitas Udayana, Bali, Indonesia, 2015.

[2] P. Kumar. "Modified Improved Sinc power Pulse for Inter Carrier Interference Reduction in OFDM System". IEEE International Conference on Recent Trends In Electronics Information Communication Technology Jurnal Telekomunikasi dan Komputer. 978-5090-0774-5/16. 2016.

[3] Shaharyar, K., Cesar, A. A., Lee, K. "Suppressing the effect of ICI power using dual sinc pulses in OFDM-based systems". Department of Electrical Engineering, University of Chile, Santiago, Chile. Int. J. Electron. Commun. (AEÜ) 70 (2016) 953-960. 2016.

[4] Utomo F.L.H. "Analisis Unjuk Kerja Coded-OFDM Melalui Kanal AWGN dan Rayleigh Fading”. Skripsi. Jurusan Teknik Elektro Fakultas Teknik Universitas Udayana, Bali, Indonesia, 2015.

[5] Vaghela J., dkk. "Performance Analysis of OFDM System Using ISP Pulse Shaping Technique". International Journal of Advanced Research in Electronics and Communication Engineering (IJARECE). Vol. 5, No.5. 2016.

[6] N. P. E. A. Yuniari., N. M. A. E. D. Wirastusi., I. G. A. K. D. D. Hartawan. "Analisis Perbandingan Performansi Sistem MC-SS MIMO dengan OFDM MIMO pada Kanal Fading”. Jurnal Teknologi Elektro. Vol. 15, No. 2. 2016.

[7] K. A. M. D. Prayoga., N. M. A. E. D. Wirastusi., I. G. A. K. D. D. Hartawan. "Analisis Unjuk Kerja Convolutional Code pada Sistem MIMO MC-DSSS Melalui Kanal Rayleigh Fading”. Jurnal Teknologi Elektro. Vol. 16, No. 2. 2017.

[8] Ashish J., Prasad P. H. K.. A "Study and Comparison of Pulse Shaping Functions for ICI Reduction in OFDM System". International Conference on Electronics, Communication and Aerospace Technology (ICECA). 978-1-5090-5686-6/17. 2017.

[9] Aryanta Dwi, dkk. "Perancangan dan Implementasi Sistem Orthogonal Division Multiplexing (OFDM) Dengan Menggunakan DSKTM320C6713". Jurnal Elektro Telekomunikasi Terapan. 2015.

[10] Subrata R.H., Gozali F. "Simulasi Teknik Modulasi OFDM QPSK Dengan Menggunakan MATLAB”. Jurnal Ilmiah Teknik Elektro, Universitas Trisakti (JETri). Vol. 12, No.2. 2015.

[11] Ananta S. Chavan, Sidhant S. Kulkarni. "Effect of Number Subcarrier on Implementation of OFDM Transceiver on FPGA". International Journal of Innovative Research in Electronics and Communications (IJIREC). Vol. 2, No. 2. 2015.

[12] Titiek Suryani., Suwadi., dkk., "Implementasi and Performance Evoluation of Orthogonal Frequency Division Multiplexing (OFDM) using WARP'. International Seminar on Intellegent Technology and Its Applications, 2015.

[13] Khedkar, A., Sumathi, M., Murugan, M. "Modified Raised Cosine Power Pulse (MRCP) Based Solution to Reduce the Sensitivity to Carrier Frequency Offset in Rayleigh Faded OFDM System”. Journal of Computational and Theoretical Nanoscience Vol. 14, 4222-4226, 2017.

[14] Sharief, A. H., Satya, S. R. "An Improved ICI Self Cancellation Scheme for OFDM Systems Under Various Channels". International Journal of Electrical and Computer Engineering (IJECE) Vol. 6, No. 2, April 2016, pp. 690 699. 2016.

[15] Rizkha, A. R. Titiek, S. S. "Implementasi dan Analisis Teknik Reduksi PAPR OFDM Menggunakan Metode PTS pada WARP”. JURNAL TEKNIK ITS Vol. 5, No. 2, ISSN: 2337-3539. 2016. 